\title{
Serangan Penyakit Rebah Kecambah Tanaman Cabai pada Tanah yang Berasal dari Persemaian Tanaman Petani di Lahan Rawa Lebak Kecamatan Pemulutan Kabupaten Ogan Ilir
}

\author{
Damping-off of Chili Pepper Growing on Seedbed Soil from Farmers in Swamp Area of \\ Pemulutan, Ogan Ilir \\ A. Muslim ${ }^{1 *}$, Suwandi Suwandi ${ }^{1}$, Muhammad Yunus Umar ${ }^{1}$ \\ ${ }^{1}$ Jurusan Proteksi Tanaman, Fakultas Pertanian, Universitas Sriwijaya, Indralaya, \\ Sumatera Selatan 30862 \\ ${ }^{*}$ Penulis untuk korespondensi: a_muslim@unsri.ac.id
}

\begin{abstract}
Research on disease severity of damping-off on chili seedling from used seedbed nursery soil from swampy area land in Pemulutan, Ogan Ilir was conducted in order to know what kind of pathogen that attack chili seddling and how is severe it's severity. This study was aimed to identify the damping-off pathogens of chili pepper and to measure inoculum potential of seedbed soil from farmers in swamp area of Pemulutan, Ogan Ilir. The experiment was conducted using survey method. The sample was taken by purposive sampling on chili seedbed nursery from six farmers all along swampy area in Pemulutan, Ogan Ilir. The result showed that observation based on the sympton and laboratory assay on damping-off disease infected chili seedling was caused by Rhizoctonia solani. The percentage of Pre-emergence damping-off incidence was ranged from 6.5-35.5\%. The highest Pre-emergence damping-off incidence was observed on soil from Mr. Mimin and lowest incidence was found from Mr. Nukman. The percentage of post-emergence damping-off incidence was ranged from $0.5-56.5 \%$, where the highest percentage was observed from Mr. Rahmat and the lowest was observed from Mr. Joni. The percentage of disease severity of damping-off was ranged from $0.55-28.75 \%$, where the highest disease severity was also observed from Mr. Rahmat and the lowest one was observed from $\mathrm{Mr}$. Nukman. Based on disease severity of chili damping-off observed in this study was high, chili damping-off disease is important disease during providing seedling. This disease was potential to reduce the quality and quantity of chili production.
\end{abstract}

Keywords: chili, diseases severity, Rhizoctonia solani Kuhn, swampy area

\section{ABSTRAK}

Penelitian tentang serangan peyakit rebah kecambah (damping-off) tanaman cabai dari tanah persemaian petani dari Lahan Rawa Lebak Kecamatan Pemulutan, Kabupaten Ogan Ilir, dilakukan dengan menggunakan metode survei. Penelitian ini dilakukan untuk mengidentifikasi patogen yang menyebabkan rebah kecambah pada persemaian cabai pada tanah yang telah digunakan oleh petani untuk pembibitan dan untuk mengetahui tingkat serangan penyakit pada tanah tersebut. Pengambilan sampel dilakukan secara sengaja (purposive sampling) yaitu tanah bekas persemaian cabai dari enam petani di sepanjang jalan Palembang Inderalaya di Kecamatan Pemulutan. Hasil pengamatan gejala serangan rebah kecambah dan analisis laboratorium patogen yang menyerang persemaian cabai dari sampel tanah persemaian di Kecamatan Pemulutan adalah Rhizoctonia solani Kuhn. Hasil 
pengamatan menunjukkan bahwa, insidensi pre-emergence damping off tanaman cabai pada tanah bekas persemain petani berkisar antara 6,5-35,5\%. Insidensi pre-emergence damping off tertinggi ditemukan pada contoh tanah pak Mimin dan insidensi preemergence damping off terendah ditemukan pada contoh tanah pak Nukman. Untuk insidensi post-emergence damping off pada pengamatan hari ke-30 menunjukkan bahwa, insidensi post-emergence damping off berkisar antara 0,5-65,5\%, dimana insidensi damping off tertinggi pada sampel tanah pak Rahmat dan insidensi damping off yang terendah ditemukan pada sampel tanah pak Joni. Sementara untuk keparahan penyakit berkisar antara 0,55-28,75\%, dimana keparahan penyakit tertinggi ditemukan pada contoh tanah pak Rahmad dan keparahan penyakit terendah terdapat pada contoh tanah pak Nukman. Tingginya serangan penyakit damping-off pada tanaman cabai ini menunjukkan pentingnya penyakit ini yang berpotensi menimbulkan kerugian bagi petani.

Kata kunci: cabai, keparahan penyakit, rawa lebak, rhizoctonia solani Kuhn

\section{PENDAHULUAN}

Cabai atau lombok (Capsicum annuum L.) merupakan tanaman sayuran buah semusim, yang diperlukan oleh seluruh lapisan masyarakat sebagai penyedap masakan dan penghangat badan (Sunaryono 1996). Menurut Rukmana (1999), cabai menempati urutan paling atas diantara delapan belas jenis sayuran komersial yang dibudidayakan di Indonesia meskipun harga pasar cabai sering naik turun cukup tajam, akan tetapi minat petani tidak pernah surut untuk membudidayakannya. Daya tarik bagi petani dalam pengembangan budidayanya terletak pada nilai ekonominya yang tinggi.

Kecamatan Pemulutan berada pada ketinggian rata-rata $0-5 \mathrm{~m}$ di atas permukaan laut. Dataran tinggi dan perbukitan tidak dijumpai. Bentuk wilayah kecamatan ini adalah datar dan sebagian besar berupa lahan rawa dan padang alangalang. Lahan rawa di daerah ini dimanfaatkan untuk penanaman padi di musin hujan dan tanaman cabai serta berbagai jenis sayur-sayuran lainnya.

Kendala yang dihadapi dalam budidaya tanaman cabai di lahan rawa, diantaranya pengelolaan tata air, perubahan iklim, dan gangguan penyakit tanaman. Rebah kecambah (damping-off) sering terjadi dipersemaian cabai atau terung. Biji yang membusuk didalam tanah atau semai dapat mati sebelum muncul kepermukaan tanah. Penyakit tersebut biasanya disebabkan oleh Rhizoctonia solani Kuhn. dan Pythium spp. (Semangun 2000).

Penelitian ini dilakukan untuk mengidentifikasi patogen yang menyebabkan rebah kecambah pada persemaian cabai pada tanah yang telah digunakan oleh petani untuk pembibitan dan untuk mengetahui tingkat serangan penyakit pada tanah tersebut.

\section{BAHAN DAN METODE}

Pengambilan sampel tanah persemaian dilakukan dengan metode survey dan penentuan sampel tanah dilakukan secara sengaja (purposive sampling). Sampel tanah diambil dari persemaian cabai milik petani di sepanjang jalan Palembang Inderalaya di Kecamatan Pemulutan yang merupakan lahan rawa lebak. Selanjutnya ditentukan 6 lahan persemaian sebagai sampel. Lahan petani yang dijadikan sampel tersebut adalah lahan persemaian cabai milik Pak Amin, Pak Edi, Pak Mimin, Pak Joni, Pak Rahmat dan pak Nukman.

Pengujian Tanah Persemaian terhadap serangan penyakit Rebah Kecambah. Setelah menentukan lahan yang akan di gunakan sebagai sampel, Setelah mendapatkan enam lahan sampel tersebut, Selanjutnya masing-masing tanah persemaian tersebut dibawa ke rumah kaca (green hause), kemudian digemburkan dan 
dicampur dengan pupuk kandang dengan perbandingan 2:1 sseperti yang biasa dilakukan petani pada saat membuat persemaian tanaman cabai. tanah yang sudah dicampur pupuk kandang tersebut kemudian dimasukkan kedalam baki yang sudah disediakan. Setiap contoh tanah di ulang dua kali masing-masing terdiri dari 100 benih.

Tanah yang digunakan sebagai kontrol berasal dari lahan pak amin. Tanah yang dijadikan kontrol tersebut sebelum digunakan disterilisasi dengan menggunakan outoklaf selama 1 jam dengan suhu kurang lebih $90^{\circ} \mathrm{C}$, selanjutnya diproses sama seperti tanah persemain lainnya.

Tanah yang sudah dimasukkan kedalam baki kemudian disiram dengan air dan didiamkan dalam kondisi lembab selama dua hari. Setelah dua hari contoh tanah tersebut ditanamai dengan benih cabai yang sudah direndam semalam, setiap baki ditanam sebanyak 100 benih. Setiap perlakuan di letakkan di rumah kaca dan diberi naungan dengan menggunakan atap untuk menjaga kelembapan persemaian cabai tersebut tetap tinggi. Pengamatan dilakukan sehari setelah tanam sampai persemaian berumur 30 hari.

\section{Gejala Serangan}

Pengamatan penyakit pada persemaian tanaman cabai dilakukan dengan melihat langsung gejala damping off pada pesemaian cabai yang ditanam di rumah kaca

\section{Penyebab}

Pengamatan untuk mengetahui penyebab penyakit dapat dilakukan secara mikroskopis di laboratorium.

\section{Insidensi Penyakit}

Rebah kecambah dibedakan menjadi dua yaitu sebelum muncul ke permukaan tanah (pre-emergence damping off) dan rebah kecambah setelah muncul ke permukaan tanah (post-emergence damping off).
Insidensi Rebah Kecambah Sebelum Muncul ke Permukaan Tanah (preemergence damping off)

Pengamatan ini dimulai sejak hari pertama dilakukan penanaman sampai 10 hari setelah penyemaian. Untuk mencari besarnya insidensi rebah kecambah sebelum muncul ke permukaan tanah dihitung dengan rumus:

$$
\mathrm{S}=\left[\frac{A-B}{A} \times 100 \%\right]-[100 \%-D]
$$

dengan,

S, insidensi rebah kecambah sebelum muncul ke permukaan tanah; A, jumlah benih yang disemai; B, jumlah kecambah yang muncul; D, Persentase daya kecambah benih.

\section{Insidensi Rebah Kecambah Setelah Muncul ke Permukaan Tanah (post- emergence damping off)}

Pengamatan ini dimulai sejak benih muncul ke permukaan tanah sampai bibit berumur 30 hari setelah penyemaian. Persentase dihitung dengan menggunakan rumus :

$$
\mathrm{K}=\frac{n}{N} x 100 \% \text {, dengan, }
$$

$\mathrm{K}$, insidensi rebah kecambah setelah muncul ke permukaan tanah; n, jumlah bibit terserang; $\mathrm{N}$, jumlah benih yang disemai.

\section{Keparahan Penyakit}

Intensitas serangan dapat dihitung dengan menggunakan rumus :

$$
\mathrm{I}=\frac{\sum(n x v)}{N x Z} \times 100 \% \text { dengan, }
$$

I, keparahan penyakit; $n$, jumlah bibit yang terserang, $\mathrm{N}$, jumlah benih yang disemai; $\mathrm{Z}$, harga numerik dari nilai katagori tertinggi; $\mathrm{v}$, harga numerik dari setiap nilai katagori 
(0-4) yaitu skor $0=$ Tanaman sehat (tidak ada serangan); skor $1=$ ada bintik kecil yang berukuran $<2,5 \mathrm{~mm}$ pada pangkal batang dan tingkat serangan antara $0-25 \%$; skor $2=$ serangan berat, bintik membesar berukuran antara $2,5-5 \mathrm{~mm}$ dan tingkat serangan antara 25-50\%; skor $3=$ serangan semakin berat, bintik semakin membesar, tanaman menjadi layu, berukuran $>5 \mathrm{~mm}$ dan tingkat serangan antara 50-80\%; skor $4=$ tanaman mati, baik pada pre-emergence damping off dan post-emergence damping off dan tingkat serangan $>80 \%$.

\section{HASIL}

\section{Gejala Penyakit}

Gejala penyakit rebah kecambah yang tampak di lapangan adalah terjadi pembusukan pada pangkal batang dekat permukaan tanah, berwarna coklat kehitaman, selanjutnya batang yang telah membusuk tersebut berkerut sehingga tanaman rebah dan mati (Gambar 1).

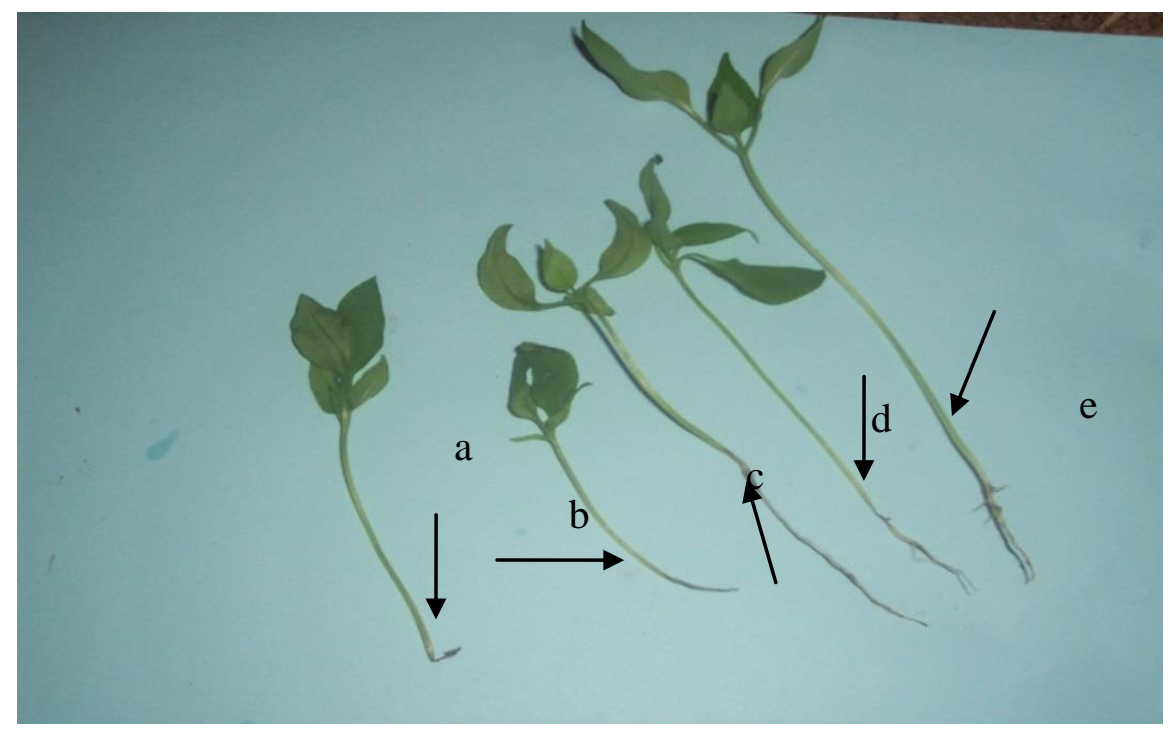

Gambar 1. Tanaman cabai yang terserang rebah kecambah. a-d adalah tanaman sakit, e adalah tanaman sehat.

\section{Penyebab Penyakit}

Hasil pengamatan pada persemaian cabai dari contoh tanah persemaian di Kecamatan Pemulutan, ditemukan satu jenis patogen yang menyerang tanaman cabai di persemaian yang diduga penyebab tersebut adalah jamur Rhizoctonia solani. Hal tersebut didasarkan pengamatan pada persemaian di rumah kaca, pre-emergence damping-off dan pengamatan dengan mengunakan mikroskop di laboratorium tidak ditemukan adanya spora, hifa bersekat dan percabangannya tegak lurus yang merupakan ciri patogen $R$. Solani (Gambar 2).

Pada leher akar tanaman muda yang sakit, terdapat lekukan yang berwarna coklat sampai hitam, sehingga tanaman mudah rebah. Jamur $R$. solani menghasilkan sklerotia dengan bentuk bervariasi, terbentuk diantara benang miselium. Sklerotia tersebut akan berkecambah membentuk miselium bila keadaan mendukung (Semangun 1996). Selanjutnya menurut Lucas and Campbell (1985), miselium $R$. solani steril, waktu muda tidak berwarna kemudian berubah menjadi kekuning-kuningan atau coklat terang sesuai dengan umur jamur tersebut. Miselium terdiri dari sel-sel hifa yang panjang dan menghasilkan cabang yang hampir tegak lurus pada hifa utama.

Hifa $R$. solani bila dilihat dengan menggunakan mikroskop fase kontras terlihat bahwa sel-sel hifa mempunyai banyak inti (2-25, umumnya 4-8) dan 
mempunyai sekat. Hifa yang lebih tua mempunyai ukuran yang bervariasi, namun sel-sel dapat menjadi lebih pendek karena pembentukan sekat-sekat sekunder (Holliday 1980).

Insidensi Penyakit Rebah Kecambah Sebelum Muncul ke Permukaan Tanah (pre-emergence damping off)

Dari hasil perhitungan insidensi preemergence damping off pada persemaian tanaman cabai dari sampel tanah persemaian di hari ke sepuluh pada kecamatan Pemulutan menunjukkan bahwa insidensi damping off berkisar antara 6,5$35,5 \%$, insidensi pre-emergence damping off tertinggi pada sampel tanah pak Mimin sebesar 35,5\%. Insidensi pre-emergence damping off terendah ditemukan pada sampel tanah pak Nukman sebesar 9,5\%, sedangkan insidensi pre-emergence damping-off pada tanah steril hanya 6,5\% (Gambar 3). Insidensi Rebah Kecambah Setelah Muncul ke Permukaan Tanah (postemergence damping-off).

Hasil perhitungan insidensi postemergence damping off pada pesemaian cabai dari sampel tanah persemaian di Kecamatan Pemulutan pada hari ke-30 menunjukkan bahwa insidensi postemergence damping off berkisar antara 0,5$56,5 \%$, insidensi post-emergence damping off tertinggi ditemukan pada sampel tanah pak Rahmat sebesar $56,5 \%$ dan insidensi post-emergence damping off yang terendah ditemukan pada sampel tanah pak Joni sebesar 3\%. Sementara post-emergence damping off pada tanah steril sangat rendah sebesar 0,5\%. ersebut (Gambar 4).

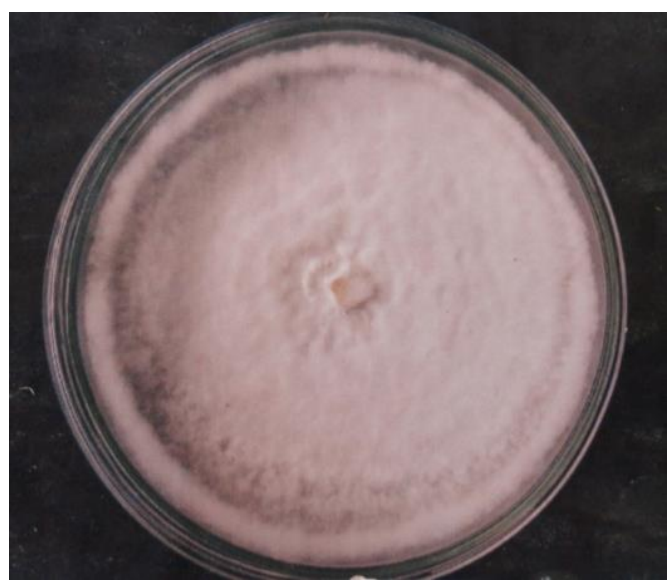

Gambar 2. Biakan jamur yang berasal dari jaringan tanaman cabai sakit pada media Potato Dextrose Agar (PDA).

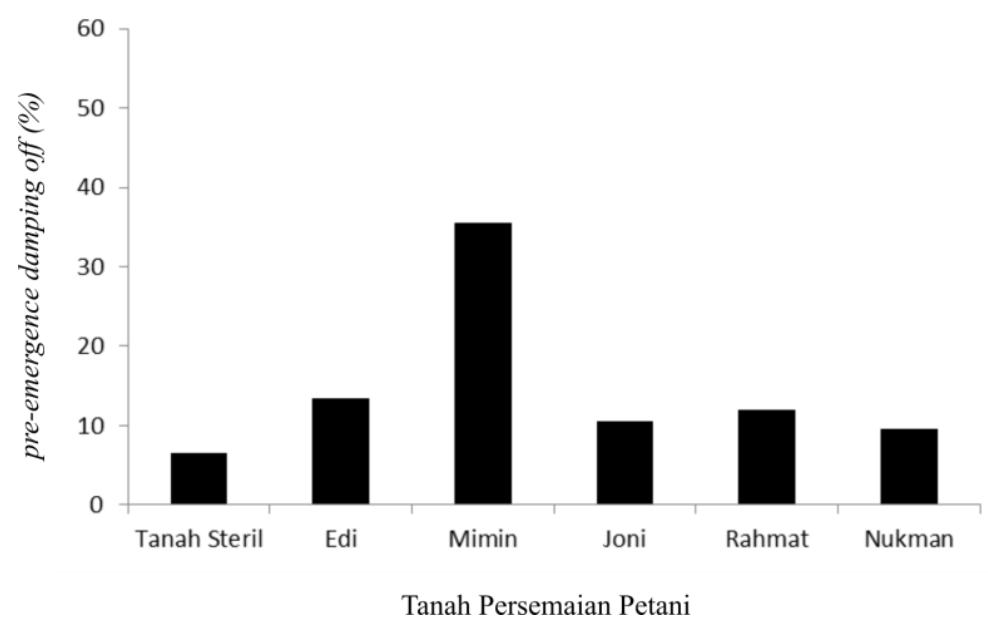

Gambar 3. Insidensi pre-emergence damping-off pada tanah dari pesemaian cabai di Kecamatan Pemulutan pengamatan dilakukan pada hari ke-10. 


\section{Keparahan Penyakit}

Berdasarkan hasil perhitungan keparahan penyakit rebah kecambah pada tanaman cabai dari sampel tanah persemaian di Kecamatan Pemulutan pada hari ke-30 diketahui bahwa keparahan penyakit berkisar antara 0,55-28,75\%. Keparahan penyakit tertinggi ditemukan pada contoh tanah pak Rahmad sebesar $28,75 \%$ dan keparahan penyakit terendah ditemukan pada contoh tanah pak Nukman sebesar 2,36\%. Sementara keparahan penyakit rebah kecambah pada tanah steril sangat rendah sebesar 0,55 lebih rendah dibandingkan dengan keparahan penyakit pada contoh tanah persemaian cabai dari kecamatan pemulutan tersebut (Gambar 5).

\section{PEMBAHASAN}

Hasil pengamatan pada tanaman sakit dengan gejala rebah kecambah (damping-off) pada persemaian cabai yang tanahnya berasal dari bekas persemaian tanaman cabai di Kecamatan Pemulutan, ditemukan satu jenis jamur patogen yaitu Rhizoctonia solani. Berdasarkan pengamatan Gejala yang tampak pada preemergence damping-off yaitu biji cabai berubah warnanya menjadi coklat kehitamhitaman dan jaringannya mengalami pembusukan sehingga biji tidak dapat berkembang menjadi benih dan akhirnya mati. Gejala pada post-emergence damping-off pada leher akar tanaman muda yang sakit terdapat lekukan yang berwarna coklat sampai hitam. Gejala ini sesuai dengan laporan Semangun (2000).

Pada tanaman yang lebih tua pada pangkal batang terdapat zone berwarna coklat dengan batas yang tegas. Patogen ini menyerang tanaman cabai dari perakaran sampai titik tumbuh, tanaman yang terserang akan menjadi layu, rebah dan akhirnya mati. Gejala yang tampak pada pre-emergence damping-off yaitu biji cabai berubah warnanya menjadi coklat kehitamhitaman dan jaringannya mengalami pembusukan sehingga biji tidak dapat berkembang menjadi benih dan akhirnya mati. Gejala pada post-emergence damping off pada leher akar tanaman muda yang sakit terdapat lekukan yang berwarna coklat sampai hitam.

Hasil penelitian memperlihatkan bahwa insidensi pre-emergence dampingoff, post-emergence damping-off, dan Keparahan penyakit rebah kecambah pada tanaman cabai cukup tinggi, berturut-turut berkisar 6,5-35,5\%, 0,5-56,5\%, dan $0,55-28,75 \%$. Tingginya insidensi penyakit damping-off pada persemaian ini mungkin disebabkan karena tanah yang diambil sebagai sampel tanah tersebut sudah terdapat inokulum dari jamur penyebab rebah kecambah. Presentase postemergence damping-off dan Keparahan penyakit rebah ditemukan pada sampel tanah dari pak Rahmat, tingginya keparahan penyakit pada contoh tanah dari pak Rahmat ini ada kemungkinan pada lahan persemaian yang dijadikan contoh sudah terdapat inokulum jamur patogen penyebab penyakit tersebut dibandingkan sampel tanah lain. Hasil wawancara memperlihatkan bahwa Tanah pak Rahmat ini secara kontinu digunakan untuk persemaian cabai, dan serangan penyakit damping-off cukup tinggi. Kemungkinan hal lain yaitu, jenis tanah pada sampel tanah pak Rahmat adalah tanah jenis lempung sehingga cenderung banyak menahan air, yang menyebabkan kelembabannya tinggi sehingga dapat mendukung proses perkecambahan jamur. Hasil temuan ini selaras dengan studi oleh Tamm et al. (2010) yang menjelaskan bahwa jenis tanah memegang peran yang sangat penting untuk serangan penyakit damping-off. Jamur yang menyerang pada persemaian tersebut merupakan jamur tanah (soil inhabitant) yang dapat bertahan lama dengan hidup saprofitik pada bahan-bahan organik di dalam tanah (Pracaya 1999), sehingga jamur tersebut muncul dan berkembang kembali ketika mendapatkan habitat dan inang yang mendukung.

Faktor-faktor yang mempengaruhi penyakit rebah kecambah ini adalah faktor lingkungan. Perkembangan penyakit rebah 
kecambah ini dibantu oleh kelembaban tanah yang sangat tinggi. Penyakit banyak terdapat di persemaian jika kecambah tidak dapat berkembang dengan cepat karena lingkungan yang tidak sesuai, dengan demikian jamur-jamur mempunyai kesempatan yang lebih besar untuk menyerangnya. Untuk mengurangi kelembaban pada persemaian dapat dilakukan dengan meningkatkan suhu seperti memberikan mulsa plastik pada media semai, penanaman yang tidak terlalu rapat dan tidak memakai peteduh yang terlalu berat (Semangun 2000). Semangun (1996), menjelaskan bahwa jamur dapat menginfeksi benih pada suhu optimum antara $15-18^{\circ} \mathrm{C}$ dan maksimum pada suhu $35^{\circ} \mathrm{C}$. Penanaman semai yang terlalu dalam juga akan meningkatkan jumlah semai yang sakit (Pracaya 1999).

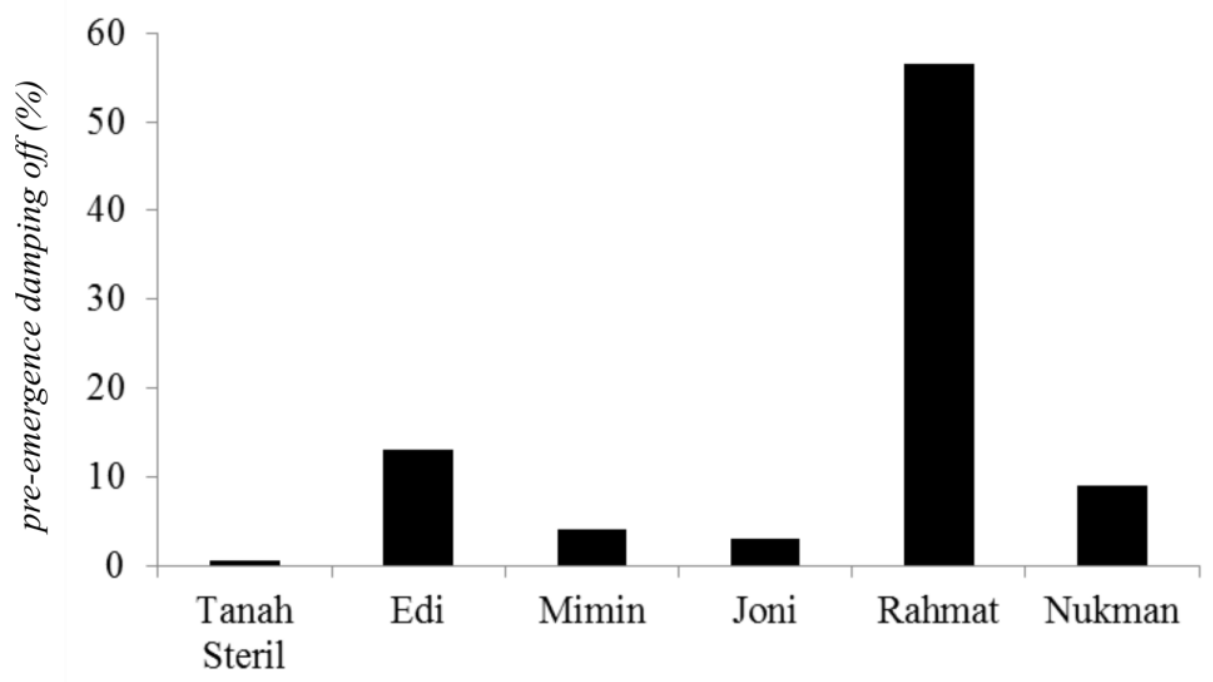

Tanah Persemaian Petani

Gambar 4. Insidensi post-emergence damping off pada tanaman cabai dari berbagai tanah persemaian di Kecamatan Pemulutan. Pengamatan dilakukan pada hari ke-30.

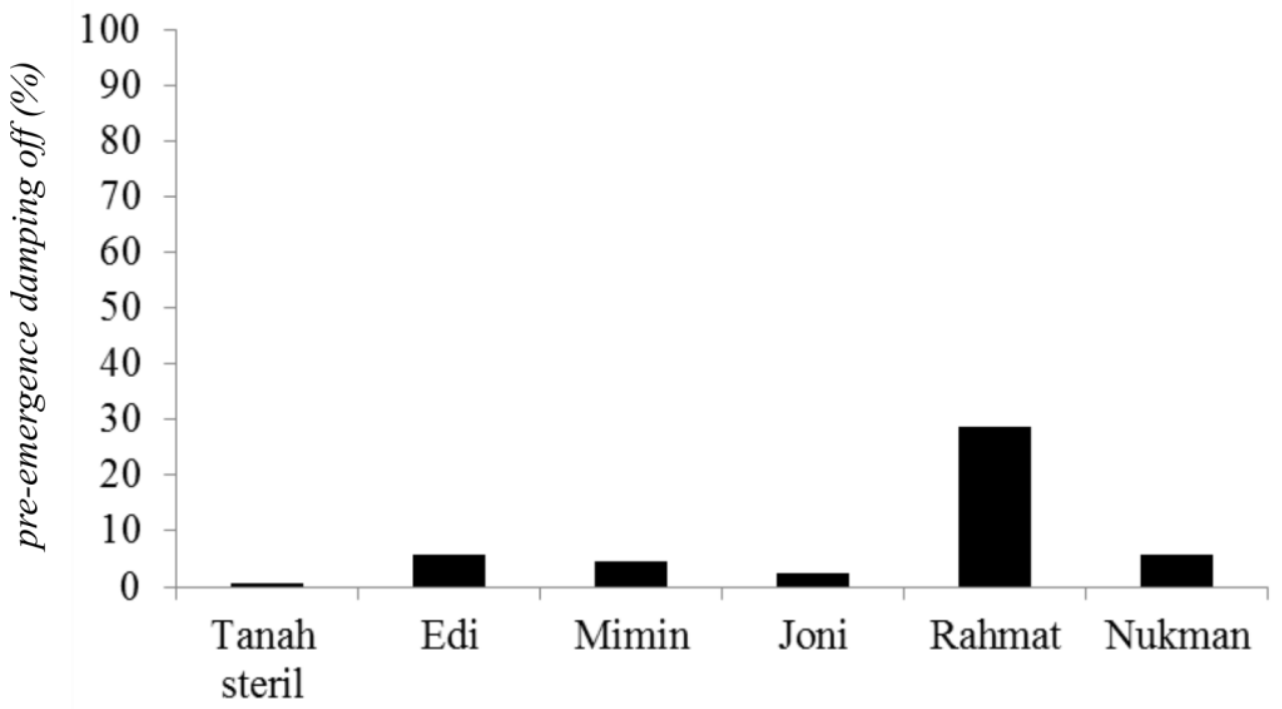

Tanah Persemaian Petani

Gambar 5. Keparahan penyakit rebah kecambah pada contoh tanah persemaian cabai dari Kecamatan Pemulutan tersebut. 
Pengendalian hayati dengan menggunakan mikoorganisme antagonist seperti, Pseudomonas aureofaciens (Samavat et al. 2014); Trichoderma harzianum SQR-T37 (SQR-T37) (Huang, 2011); cendawan endofit Muscodor cinnamomi CMU-Cib 4 (Suwannarach et al. 2012) juga sangat efektif dalam menekan penyakit Rhizoctonia damping off.

Penggunan pestisida anjuran merupakan bentuk pengendalian secara kimiawi, menurut Direktorat Sarana Produksi, Direktorat Jendral Tanaman Pangan, Departemen Pertanian (2006), pestisida yang dianjurkan untuk pengendalian $R$. solani dan Pythium sp. pada pembibitan dan persemaian adalah Altan $20 \mathrm{WP}$, Antracol $70 \mathrm{WP}$, Cupravit OB 21, Delsena MX 80 WP, Dhitane M-45 80 WP, Nemispor 80 WP, Polycom 80 WP, Previcur-N, Proplant 722 SC, Rizolex 50 $\mathrm{WP}$, vondozeb $80 \mathrm{WP}$.

\section{DAFTAR PUSTAKA}

$\begin{array}{lrr}\text { Direktorat Sarana } & \text { Produksi } & \text { Direktorat } \\ \text { Jendral } & \text { Tanaman } & \text { Pangan } \\ \text { Depertemen } & \text { Pertanian. } & 2006 . \\ \text { Pestisida Terdaftar Pertanian dan } & \\ \text { Kehutanan. }\end{array}$

Holliday P. 1980. Fungus Diseases of Tropical Crops. Cambridge University Press. Cambridge.

Huang X, Lihua CL, Wei RW, Shen Q, dan Yang X. 2011. Trichoderma harzianum strain SQR-T37 and its bio-organic fertilizer could control Rhizoctonia solani damping-off disease in cucumber seedlings mainly by the mycoparasitism. Appl Microbiol Biotechnol 91:741-755.

Lucas GB dan Campbell CL. 1985. Introduction to Plant Diseases. Van Nostrand Reinhold. New York.
Pracaya. 1999. Hama dan Penyakit Tanaman. Jakarta: Penebar Swadaya.

Rukmana R. 1999. Usaha Tani Cabai Hibrida Sistem Mulsa Plastik. Kanisius. Yogyakarta

Samavat S, Heydari A, Zamanizadeh HR, Rezaee S, dan Aliabadi AA. 2014. Application of new bioformulations of Pseudomonas aureofaciens for biocontrol of cotton seedling damping-off. Journal of Plant Protection Reseach Poznan. 54:334339.

Semangun H. 1996. Pengantar Ilmu Penyakit Tumbuhan. Gadjah Mada University Press. Yogyakarta

Semangun H. 2000. Penyakit-penyakit Tanaman Hortikultura di Indonesia. Yogyakarta: Gadjah Mada University Press

Sunaryono A. 1996. Budidaya Cabai Merah. Sinar Baru Algensindo. Bogor.

Suwannarach N, Kumla J, Bussaban B, dan Lumyong S. 2012. Biocontrol of Rhizoctonia solani AG-2, the causal agent of damping-off by Muscodor cinnamomi CMU-Cib 4. World J Microbiol Biotechnol. 28:31713177.

Tamm L, Thürig B, Christian BCH, Fuchs JG, Köpke U, Laustela M, Leifert C, Mahlberg N, Nietlispach B, Christoph Schmidt Ch, Weber F, dan Fließbach A. 2010. Soil type, management history, and soil amendments influence the development of soil-borne (Rhizoctonia solani, Pythium ultimum) and air-borne (Phytophthora infestans, Hyaloperonospora parasitica) diseases. Eur J Plant Pathol. 127:465-481. 